\title{
Performance and Carcass Characteristics of Growing Rabbits Fed Diets Containing Different Fibrous Ingredients
}

\author{
O. Olanike Adejinmi ${ }^{1}$, O. Michael Odetola ${ }^{1} \& \mathrm{~J}$. Adeboye Omole ${ }^{2}$ \\ ${ }^{1}$ Federal College of Animal Health and Production Technology, P.M.B 5029, Moor Plantation, Ibadan, Nigeria \\ ${ }^{2}$ Institute of Agricultural Research and Training, P.M.B 5029, Moor Plantation, Ibadan, Nigeria \\ Correspondence: O. Olanike Adejinmi, Federal College of Animal Health and Production Technology, P.M.B \\ 5029, Moor Plantation, Ibadan, Nigeria. E-mail: funmiolanike@yahoo.co.uk
}

Received: May 5, 2013 Accepted: July 2, 2013 Online Published: August 15, 2013

doi:10.5539/jas.v5n9p198 URL: http://dx.doi.org/10.5539/jas.v5n9p198

\begin{abstract}
An experiment was conducted to assess the performance and carcass characteristics of growing rabbits fed different fibre sources in a completely randomised design. Totally 30 rabbits of mixed sexes at the age of 8 weeks (56 days) were randomly allocated to five dietary groups averaging $500.00 \pm 27.26$. The fibre sources are: wheat offals, rice bran, palm kernel cake, maize bran and brewer dried grain. Data were collected on the feed intake and weight gain while carcass characteristics was evaluated at week 12 of the experiment. Results revealed significant $(p<0.05)$ differences in the values obtained for weight gain and feed conversion ratio (FCR). Average weight gain ranged from 10.95 to $16.70 \mathrm{~g}$ /day, while FCR ranged from 4.38 to 6.85 . Feed cost per weight gain ranged from \#379.79 to $\$ 636.98$, while the saving $/ \mathrm{kg}$ gain ranged from $\mathrm{N}-14.28$ to $\$ 224.9$. Among the cut parts and organs examined, hind limb, back, neck, lungs and heart were significantly $(p<0.05)$ influenced by dietary treatment. The results suggest that rabbits have the capacity to utilize fibrous feed effectively, but can perform better on maize offal and brewers dried grains.
\end{abstract}

Keywords: rabbits, wheat offal, rice bran, maize bran, palm kernel cake, feed efficiency and dressing percentage

\section{Introduction}

The ever- increasing population growth in the developing countries means a greater demand for animal protein which is already in short supply in this region. The animal shortage is due largely to low level of animal productivity. Rabbits produce healthy meat that is suitable for producing healthy people, because of its low salt and fat content, being a white meat like poultry. The recent understanding of the usefulness of the meat for diabetics, hypertensive and middle aged people has further raised awareness on the production of rabbits, thus increasing the demand for rabbit meat (Iyeghe-Erakpotobor et al., 2012). Animal protein contain essential amino-acids, which helps in the body tissue synthesis, replenishing the nitrogen lost in urine, faeces, saliva, desquamated skin, hair and nails. Protein also supplies a level of energy and growth, increase body immunities (Iwena, 2000).

The cost of conventional feed ingredient such as maize has been on the increase from year to year leading to increase in the price of animal protein sources (Adejinmi et al., 2007). The competition between man and livestock for these feed ingredients coupled with their high cost call for search for alternative non-conventional feed ingredient that would be used in place of conventional feed ingredients.

The utilization of agro-industrial by-products in animal feed has increased so as to reduce the cost of feed ingredients. Agro-industrial by-products are waste products arising from the processing of crops or animals products usually by an agro-industrial firm. Agro-industrial by-products which can be of tremendous use in the livestock for feeding includes brewer's dried grain, cassava peel, orange pulp, rice bran, maize bran and palm kernel cake. These agro-industrial wastes are by-products of sorghum, cassava, pineapple, maize and palm oil processing

Brewer's dry grain (BDG) is a solid waste from brewery industries. It is available and cheap but difficult to dry due to its high moisture content for easy storage and use especially during the wet season. There is a wide variation in the proximate composition of BDG depending on the brewery that produce it (Oyediji, 2001). BDG contains about $19-25 \%$ crude protein, $10-22 \%$ crude fibre, ME of $7.38 \mathrm{MJ} / \mathrm{kg}$ and gross energy of $3030-3170 \mathrm{Kcal} / \mathrm{kg}$ (Olupona et al., 2002). Wheat offal is a by-product of wheat after obtaining flour. Wheat offal contains $11.80-17.60 \% \mathrm{CP}$, 
about $10 \%$ crude fibre and 3.40-6.40\% crude ash (Olomu, 1995). The lower crude fibre content makes wheat offal's suitable for feeding monogastric animals. Palm kernel cake is obtained after extracting most of the oil from palm kernel seeds. It is readily available and cheap, it contains $12-14 \%$ crude protein and $10-20.5 \%$ crude fibre (Oyenuga, 1998), but its utilization is limited by its grittiness, dryness in texture, high fibre content and low palatability (Olomu, 1995). Rice bran is obtained from milling or processing of rice. It is high in fibre and also in oil, the latter constituents may cause problem of rancidity of feed during storage. It has a crude protein content of $12.50 \%$ and crude fibre of $12.5 \%$. This study was undertaken to evaluate the effect of feeding different fibrous ingredients on the performance and carcass characteristics of weaned rabbits.

\section{Materials and Methods}

\subsection{Experimental Rabbits and Management}

Thirty (30), 56 - day old (New Zealand x Chinchilla) rabbits weighing averagely $500.00 \pm 27.26$ g were used in a 12 weeks feeding trial conducted to evaluate the effects of feeding different fibrous ingredients on the performance and carcass characteristics of growing rabbits.

Five experimental diets containing equal quantity of the fibrous ingredients were formulated. Treatment one (T1) contained wheat offal which served as the control, while treatments (T2 - T5) contained rice bran, palm kernel cake, maize bran and brewer dry grain respectively (Table 1). After a 7 days acclimatization period, the rabbits were randomly distributed into five groups of 6 rabbits each, which were further divided into three replicates of 2 rabbits per replicate in a completely randomized design (CRD). The animals were housed in groups of two in a wire meshed cage. Feed and water were supplied ad libitum. Data were collected on feed intake and weight gain.

Table 1. Gross composition of the experimental diets

\begin{tabular}{lccccc}
\hline Ingredients (\%) & Wheat offals & Rice bran & Palm kernel cake & Maize bran & Brewer dried grain \\
\hline Maize & 34.14 & 29.14 & 34.14 & 29.14 & 36.14 \\
Soya bean meal & 18.80 & 23.80 & 18.80 & 23.80 & 16.90 \\
Wheat offal & 35.00 & - & - & - & - \\
Rice bran & - & 35.00 & - & - & - \\
Palm kernel cake & - & - & 35.00 & - & - \\
Maize bran & - & - & - & 35.00 & - \\
Brewers' dried grain & - & - & - & - & 35.00 \\
Corn cob & 10.00 & 10.00 & 10.00 & 10.00 & 10.00 \\
Bone meal & 2.00 & 2.00 & 2.00 & 2.00 & 2.00 \\
Salt & 0.25 & 0.25 & 0.25 & 0.25 & 0.25 \\
Vitamin and mineral premix & 0.25 & 0.25 & 0.25 & 0.25 & 0.25 \\
Lysine & 0.10 & 0.10 & 0.10 & 0.10 & 0.10 \\
Methionine & 0.10 & 0.10 & 0.10 & 0.10 & 0.10 \\
\hline Total & 100.00 & 100.00 & 100.00 & 100.00 & 100.00 \\
Calculated Analysis & & & & & \\
Metabolizable energy (Kcal/kg) & 2239.15 & 2904.00 & 2346.00 & 2420.00 & 2626.00 \\
Crude protein & 16.97 & 16.82 & 17.32 & 16.47 & 18.93 \\
Crude fibre (\%) & 7.94 & 9.57 & 9.16 & 9.39 & 12.69 \\
\hline
\end{tabular}

\subsection{Carcass Evaluation}

At the end of the feeding trial, three rabbits were randomly selected from each treatment based on the average group weight for carcass analysis. The animals were starved for twelve hours and their weights taken prior to bleeding. Bleeding of the rabbits involved severing their jugular veins with a sharp knife followed by flaying. The heart, lungs, kidney and liver were carefully removed and weighed. The weight of the dressed carcass, head, legs and skin were also weighed and recorded. 


\subsection{Chemical Analysis}

The proximate composition of the test ingredients and experimental diets were carried out as outline by AOAC (2007).

\subsection{Statistical Analysis}

All the data generated were subjected to analysis of variance (ANOVA) procedure of SAS (2003) in a completely randomized design. Duncan multiple range test of the same software was used to compare the treatment means if found to be significantly different.

\section{Results}

The proximate composition of the different fibrous ingredient is as shown in Table 2, while the proximate composition of the test diets were presented in Table 3. Table 4 and 5 show the performance characteristics of the experimental animals and their carcass characteristics respectively. There were significant $(p<0.05)$ differences in average daily weight gain and feed conversion ratio. Rabbits on T4 (maize offals) had the highest daily weight gain $(16.70 \mathrm{~g})$, while those on the control diet (wheat offals), had the lowest daily weight gain (10.95 g). The results also revealed that rabbits on T4 and T5 had similar weight gain, which was significantly $(\mathrm{p}<0.05)$ higher than those on T1, T2 and T3. There was significant $(\mathrm{p}<0.05)$ dietary effect of the fibrous ingredients on FCR. Rabbits on maize bran (T4) and brewers dried grain (T5) had similar FCR which was significantly better than what was recorded for rabbits on other forms of fibrous ingredient. The results of cost benefit ratio revealed significant $(\mathrm{p}<0.05)$ differences in the mean values obtained for all parameters measured (Table 3). Diet T4 (maize bran) had the highest cost ( $\# 100.04 / \mathrm{kg})$ of feed, while Diet T5 had the lowest $(\$ 89.19 / \mathrm{kg})$ of feed. However, rabbits on T3 recorded highest cost of feed consumed per rabbit per day while those on T5 had the lowest. The cost of feed consumed per weight gain revealed that rabbits on T3 (PKC) had the highest while those on T5 (BDG) and maize bran recorded the lowest cost $/ \mathrm{kg}$ gain. Saving $/ \mathrm{kg}$ was $\#-14.28$ - $\$ 224.91$ compared with the wheat offals.

The result of the carcass composition revealed significant $(\mathrm{p}<0.05)$ differences in the mean values obtained for hind limbs, back, neck, lungs and heart. A range of $(24.42-21.54 \%)$ was obtained for the hind limbs; back (11.46 $-8.83 \%)$; neck $(2.27-1.40 \%)$; lungs $(0.93-0.64 \%)$; and heart $(0.45-0.21 \%)$.

Table 2. Proximate composition of the test ingredients

\begin{tabular}{lccccc}
\hline Parameters (\%) & Wheat offals & Rice bran & Palm kernel cake & Maize bran & Brewer dried grain \\
\hline Dry matter & 86.20 & 87.30 & 87.20 & 92.30 & 92.50 \\
Crude protein & 18.14 & 12.06 & 17.92 & 11.10 & 18.90 \\
Crude fat & 2.56 & 11.76 & 4.59 & 2.70 & 3.04 \\
Crude fibre & 7.55 & 7.76 & 10.66 & 8.24 & 9.95 \\
Ash & 10.08 & 10.65 & 10.97 & 11.75 & 16.47 \\
Nitrogen free extract & 47.87 & 45.07 & 43.06 & 58.51 & 44.14 \\
\hline
\end{tabular}

Table 3. Proximate composition of the experimental diet

\begin{tabular}{lccccc}
\hline Parameters (\%) & Wheat offals & Rice bran & Palm kernel cake & Maize bran & Brewer dried grain \\
\hline Dry matter & 88.80 & 89.60 & 86.10 & 89.68 & 89.86 \\
Crude protein & 16.19 & 16.04 & 16.39 & 15.69 & 20.69 \\
Crude fat & 3.34 & 3.00 & 9.34 & 4.43 & 3.18 \\
Crude fibre & 7.05 & 9.62 & 9.18 & 9.02 & 10.37 \\
Ash & 14.36 & 17.61 & 13.51 & 14.44 & 17.32 \\
Nitrogen free extract & 47.86 & 43.33 & 37.68 & 46.10 & 38.30 \\
\hline
\end{tabular}


Table 4. Performance characteristics of rabbits fed different fibrous ingredients

\begin{tabular}{lcccccc}
\hline Parameters (\%) & T1 & T2 & T3 & T4 & T5 & SEM \\
\hline Initial weight (g) & 516.67 & 516.67 & 516.67 & 500.00 & 500.00 & 27.26 \\
Final weight (g) & 1350.00 & 1425.00 & 1450.00 & 1666.67 & 1600.00 & 48.94 \\
Weight gain (g/rabbit/day) & $10.95^{\mathrm{b}}$ & $12.97^{\mathrm{ab}}$ & $13.10^{\mathrm{ab}}$ & $16.70^{\mathrm{a}}$ & $15.71^{\mathrm{a}}$ & 8.39 \\
Feed intake (g/rabbit/day) & 70.13 & 76.04 & 82.46 & 69.27 & 63.89 & 37.18 \\
Feed conversion ratio & $6.50^{\mathrm{a}}$ & $5.98^{\mathrm{ab}}$ & $6.85^{\mathrm{a}}$ & $4.38^{\mathrm{b}}$ & $4.46^{\mathrm{b}}$ & 0.56 \\
Mortality (\%) & 33.33 & 16.67 & 0.00 & 33.33 & 33.33 & 6.69 \\
Cost/kg of feed (\$) & $95.80^{\mathrm{ab}}$ & $90.25^{\mathrm{b}}$ & $92.99^{\mathrm{b}}$ & $100.08^{\mathrm{a}}$ & $89.19^{\mathrm{b}}$ & 2.30 \\
Cost of feed intake/rabbit/day (\$) & $67.18^{\mathrm{ab}}$ & $68.63^{\mathrm{ab}}$ & $76.68^{\mathrm{a}}$ & $69.30^{\mathrm{ab}}$ & $56.98^{\mathrm{b}}$ & 2.11 \\
Cost of feed consumed/wgt. gain (\$) & $622.70^{\mathrm{a}}$ & $539.70^{\mathrm{ab}}$ & $636.98^{\mathrm{a}}$ & $438.22^{\mathrm{b}}$ & $397.79^{\mathrm{b}}$ & 4.65 \\
Saving/kg gain (\#) & - & 83.00 & -14.28 & 184.48 & 224.91 & - \\
\hline
\end{tabular}

a,b,c; mean with difference superscript are significantly different $(\mathrm{p}<0.05)$.

$\mathrm{T} 1=$ Wheat offals, $\mathrm{T} 2=$ Rice bran, $\mathrm{T} 3=$ Palm kernel cake, $\mathrm{T} 4=$ Maize bran, $\mathrm{T} 5=$ Brewer dried grain.

Table 5. Carcass characteristics of Rabbits fed with different Fibrous ingredients (\% live weight)

\begin{tabular}{lcccccc}
\hline Parameters & T1 & T2 & T3 & T4 & T5 & SEM \\
\hline Live weight (kg) & 1.47 & 1.43 & 1.30 & 1.55 & 1.52 & 0.05 \\
Head & 10.01 & 9.98 & 10.51 & 9.64 & 8.96 & 0.22 \\
Dressing & 60.06 & 60.34 & 63.48 & 63.89 & 57.94 & 1.23 \\
Hind limb & $21.54^{\mathrm{b}}$ & $22.40^{\mathrm{ab}}$ & $24.42^{\mathrm{a}}$ & $23.34^{\mathrm{ab}}$ & $21.83^{\mathrm{b}}$ & 0.37 \\
Fore limb & 8.73 & 8.48 & 9.70 & 9.38 & 8.50 & 0.21 \\
Back & $8.83^{\mathrm{b}}$ & $9.53^{\mathrm{ab}}$ & $10.82^{\mathrm{ab}}$ & $11.46^{\mathrm{a}}$ & $8.75^{\mathrm{b}}$ & 0.40 \\
Loin & 9.83 & 10.79 & 11.51 & 11.61 & 12.48 & 0.46 \\
Neck & $1.40^{\mathrm{b}}$ & $1.67^{\mathrm{ab}}$ & $2.02^{\mathrm{ab}}$ & $1.75^{\mathrm{ab}}$ & $2.27^{\mathrm{a}}$ & 0.12 \\
ORGANS & & & & & & \\
Kidney & 0.76 & 0.75 & 0.83 & 0.78 & 0.68 & 0.03 \\
Liver & 3.13 & 2.54 & 2.76 & 3.01 & 2.64 & 0.10 \\
Lungs & $0.76^{\mathrm{ab}}$ & $0.75^{\mathrm{ab}}$ & $0.93^{\mathrm{a}}$ & $0.64^{\mathrm{b}}$ & $0.83^{\mathrm{ab}}$ & 0.04 \\
Heart & $0.45^{\mathrm{a}}$ & $0.33^{\mathrm{ab}}$ & $0.29^{\mathrm{ab}}$ & $0.35^{\mathrm{ab}}$ & $0.21^{\mathrm{b}}$ & 0.03 \\
Gastro intestinal tract & 23.41 & 19.12 & 20.83 & 18.17 & 20.78 & 1.05 \\
Spleen & 0.07 & 0.07 & 0.10 & 0.30 & 0.06 & 0.05 \\
\hline
\end{tabular}

a,b,c; mean with difference superscript are significantly different $(\mathrm{p}<0.05)$.

$\mathrm{T} 1=$ Wheat offals, $\mathrm{T} 2=$ Rice bran, $\mathrm{T} 3=$ Palm kernel cake, $\mathrm{T} 4=$ Maize bran, $\mathrm{T} 5=$ Brewer dried grain.

\section{Discussion}

There were significant differences in the average weight gain and feed conversion ratio despite the fact the animals consumed similar quantity of feed. The average feed intake of 63.89-82.46 g per animal per day observed in this study was quite high compared with the value of 51.28-71.88 g reported by Attah and Ekpeyong (1998), 60.08 $62.86 \mathrm{~g}$ reported by Agunbiade et al. (1999) for the same species of animal. The result obtained in this study compared favourably with the values of 77.64-87.51 g reported by Attah et al. (2011). Rabbits fed on T4 and T5 had similar weight gain which was significantly higher than those on other fibrous sources which shows a better utilization by the animals. The weight gain of $10.95-16.70 \mathrm{~g}$ per rabbit per day were lower than $17.65-18.57$ $\mathrm{g}$ /day reported by Agunbiade et al. (1997) and 18.00 - $20.00 \mathrm{~g}$ /day reported by Aduku et al. (1998), but was higher 
than $4.94-14.80 \mathrm{~g} /$ day reported by Bawa et al. (2005) and $8.70-9.91 \mathrm{~g} /$ day reported by Iyeghe-Erakpotobor et al. (2012) who fed rabbits on different levels of groundnut haulms. The value $4.38-6.85$ obtained for feed conversion ratio in this study indicate a lower feed utilization when compared to $2.93-4.20$ obtained by Oyewole and Nelson (1998) but higher utilization than 5.33 - 7.43 obtained by Attah and Ekpeyong (1998). Several factors including the nature of the feed and age of the animal are known to affect FCR. Lower feed cost $/ \mathrm{kg}$ gain and higher saving $/ \mathrm{kg}$ gain obtained with rabbits on BDG and maize bran indicates the potential of reducing cost of producing rabbits on these fibrous ingredients. This is in agreement with the findings of Iyeghe-Erakpotobor et al. (2012), who reported a lower feed gain $/ \mathrm{kg}$ and higher savings in rabbits fed varying levels of groundnut haulms. The results also agrees with Olorunsanya et al. (2001) who also emphasized that not only did fibre have an effect on feed intake, average daily weight gains and feed efficiency. The profit obtained from meat animal depends on the carcass quality and feed conversion or feed efficiency ratio. Hunton (1972) identified nutrition, age, sex, environment, stage of development, efficiency of feed utilization as determinants of carcass quality. The non significant effect of the diets on the prime cut is an indication of better utilization of the fibre ingredient by the animals. The percentage weight of the kidney, liver, lung and heart did not follow any regular pattern, hence did not revealed any particular influence of the fibous ingredients on the organ of the animals. This findings agrees with the reports of Adewunmi et al. (2000) who reported that the relative weight of the liver, kidney, heart and spleen of the rabbits were not affected by the source of fibre.

\section{Conclusion}

From the result above, it can be concluded that rabbits fed with maize bran and brewer dried grain recorded the best final weight, weight gain, feed conversion ratio, lower feed cost $/ \mathrm{kg}$ gain and higher savings $/ \mathrm{kg}$ gain. Therefore, brewers dried grain and maize bran could be used as fibre sources in the diet of growing rabbit without any detrimental effects on performance and carcass characteristics.

\section{References}

A.O.A.C. (2007). The official method of Analysis. Association of official Analytical chemist $18^{\text {th }}$ edition Washington D.C.

Adejinmi, O. O., Hamzat, R. A., \& Fapounda, J. B. (2007). Performance and nutrient digestibility of rabbit fed fermented and unfermented cocoa pod husk. Nigerian Journal of Animal Production, 34(1), 63-68.

Adewunmi, M. K., Sokunbi, O. A., Adejumo, D. O., Omojola, A. B., \& Anurudu, N. F. (2000). Effect of different fibre source on performance and physiological response of pre-pubertal male raabits. Dept. Of Animal Science. University of Ibadan.

Aduku, A.O., \& Olukosi, J. O. (1990). Rabbit Management in the tropics. Living Books series G.U. Publications, Abuja FCT.

Aduku, O. A., Dima, N. I., \& Aganga, A. A. (1988). A note on comparative evaluation of palm kernel meal, pea-nut meal and sunflower meal in diets of weaned rabbits. Journal of Applied Rabbit Research, 11, 264-265.

Agunbiade, J. A., Adeyemi, O. A., Fasina, O. E., Ashorobi, B. O., Adebanjo, M. O., \& Waide, O. A. (1999). Cassava peels and leaves in the diets of rabbits: Effect on performance and carcass characteristics. Nigerian Journal of Animal Production, 26, 29-34.

Attah, S., \& Ekpeyong, T. E. (1998). Performance of growing rabbits as influenced by diets containing sodium hydroxide treated and untreated rice husk. Proceedings of Silver Anniversary Conference of the Nigerian Society for Animal Production and West African Society for Animal Production. Adset/CASLP-UA Abeokuta Nigeria (pp. 608-609).

Attah, S., Ortserga, D. D., \& Anugwa, F. O. I. (2011). Effect of replacement of rice offal levels of melon (Citrullus vulgaris) seed offal on performance of growing rabbits. Nigerian Journal of Animal Production, 38(2), 67-73.

Bawa, G. S., Orunmuyi, M., \& Onabanjo, O. A. (2005). Effect of dietary inclusion levels of mechanically extracted neem seed cake on performance of young rabbits. Nigerian Journal of Animal Production, 32(2), 233-239.

Iwena, A.O. (2002). Essential Agricultural Science for Senior Secondary School.

Iyeghe-Erakpotobor, G. T., Tudunwada, I. K., Tijani, A., Muhammad, I. R., \& Bello, N. (2012). Influence of level of groundnut haulms and feeding system on performance of growing rabbits. Nigerian Journal of Animal Production, 38(1), 64-73. 
Olomu, J. M. (1980a). Monogastric Animal Nutrition. Jachem Publications.

Olomu, J. M. (1980b). Protein and Energy Nutrition of Poultry in Nigeria (pp 41-58). Published by Nigerian Branch of World Poultry Science Association.

Olorunsanya, B., Ayoola, M. A., Fayeye, T. R., Olagunju, T. A., \& Olorunsanya, E. O. (2001). Effect of replacing maize with sun-dried cassava waste meal on growth-type rabbits. Animal Production Department, University of Ilorin, Kwara State, Nigeria.

Olupona, J. A., Abodunwa, O. O., Adejinmi, O. O., Ogunleke, F. O., Fapounda, J. B., \& Olubodun, A. (2002). Performance of rabbits fed brewers dried grain from different sources. Proceedings of $27^{\text {th }}$ Annual Conference, Nigeria Society of Animal Production (NSAP) (pp 239-241). March 17-21, 2002. Fed. University of Tech. Akure, Nigeria.

Oyenuga, V. A. (1987). Nigerian feeds and feeding stuff, their chemistry and nutritive values. Heinemann Educational Books, Ibadan.

SAS. (2003). SAS/STAT Users Guide: Version 8 for Windows. SAS Istitute Inc., Cary, NC., USA.

\section{Copyrights}

Copyright for this article is retained by the author(s), with first publication rights granted to the journal.

This is an open-access article distributed under the terms and conditions of the Creative Commons Attribution license (http://creativecommons.org/licenses/by/3.0/). 